\title{
System transportu przyczep drogowych po torach kolejowych i tramwajowych
}

\begin{abstract}
W artykule zaprezentowano koncepcje transportu przyczep drogowych po torach kolejowych i tramwajowych. Przedstawiono strukturę budowy wózków transportowych tocznych $i$ napędnych. Pokazano przykładowe wyposażenie przyczep $w$ urzadzenia do obstugi i naprawy sieci trakcyjnej kolejowej lub tramwajowej. Koncepcję opracowano w ramach działalności statutowej Instytutu, finansowanej ze środków Ministerstwa Nauki i Szkolnictwa Wyższego.
\end{abstract}

\section{Wstęp}

Celem prezentowanej koncepcji jest stworzenie możliwości wykorzystania przyczep drogowych zarówno w ruchu drogowym, jak i w ruchu kolejowym. Problem ten dotychczas rozwiązywano budując pojazdy dwudrogowe (szynowo - drogowe) w oparciu o pojazdy samochodowe i ciagniki rolnicze. Pojazdy te wyposaża się w szynowy układ jezdny zabudowany na stałe na pojeździe, a nadwozie adaptuje w zależności do potrzeb i przeznaczenia pojazdu. Pojazdy te są zazwyczaj kosztowne i skomplikowane w swojej budowie. Zrealizowanie koncepcji transportu przyczep drogowych po torach jest możliwe przez zastosowanie specjalnych wózków transportowych, na których sa posadowione koła przyczepy. W ten sposób można przewozić torami kolejowymi lub tramwajowymi pojedyncze przyczepy lub tworzyć krótkie pociagi złożone np. dwóch do trzech przyczep, ciaggnionych za pomocą np. ciagnika szynowo-drogowego. Nadwozia przyczep można wyposażyć w urządzenia specjalistyczne pozwalające np. na prowadzenie prac budowlanych i remontowych torowisk kolejowych lub tramwajowych, sieci trakcyjnych, do czyszczenia infrastruktury kolejowej i tramwajowej lub innych robót prowadzonych na torowiskach. System przeznaczony jest do ruchu manewrowego w rejonie prowadzonych inwestycji budowlanych lub remontowych. Przyczepy na wózkach transportowych można eksploatować na torach w małych odległościach od bazy postojowej lub mogą być przetransportowane na duże odległości na własnych kołach po sieci dróg kołowych i ponownie wstawione na kolejowe wózki transportowe.

Celowość zastosowania systemu można uzasadnić na następującym przykładzie. W ostatnich latach $\mathrm{w}$ Polsce powstało wiele prywatnych firm budowlanych, które biorą udział $\mathrm{w}$ procesach inwestycyjnych prowadzonych na PKP oraz w przedsiębiorstwach tramwajowej komunikacji miejskiej. Modernizacja i naprawa infrastruktury torowej i sieciowej wymaga zaangażowania specjalistycznego sprzętu np. pociagów do budowy i naprawy sieci trakcyjnej oraz możliwie szybkiej i łatwej zmiany miejsca budowy. Istniejące szynowe pojazdy sieciowe $\mathrm{z}$ niezbędnym wyposażeniem specjalistycznym są ,przywiązane" do toru, natomiast mobilne pojazdy szynowo -drogowe mają $\mathrm{z}$ reguły ograniczone wyposażenie $\mathrm{z}$ uwagi na gabaryty pojazdu. Niezbędne urządzenia do budowy lub naprawy sieci trakcyjnej można zabudować na dwóch lub trzech przyczepach drogowych tworząc mobilny pociag sieciowy. W przypadku zmiany placu budowy oddalonego nawet o kilkaset kilometrów, istnieje możliwość rozmontowania pociąu oraz szybkie i tanie (przy obecnie obowiązujących taryfach opłat za użytkowanie infrastruktury drogowej i kolejowej) przetransportowanie pojedynczych przyczep droga kołowa, a następnie ponowne jego zmontowanie na nowym placu budowy.

\section{Opis ogólny systemu i procesu montażu pocią- gu}

System jest złożony $\mathrm{z}$ przyczepy 1, wózków transportowych 2 oraz pojazdu trakcyjnego np. ciągnika szynowo-drogowego 3 (rys. 1). Pojazdem trakcyjnym może być również lokomotywa manewrowa po jej wyposażeniu w odpowiedni adapter zamocowany na zderzakach, umożliwiający połączenie dyszla przyczepy z lokomotywą.

Sposób posadowienia przyczepy na wózkach transportowych pokazano na rys 2 . 


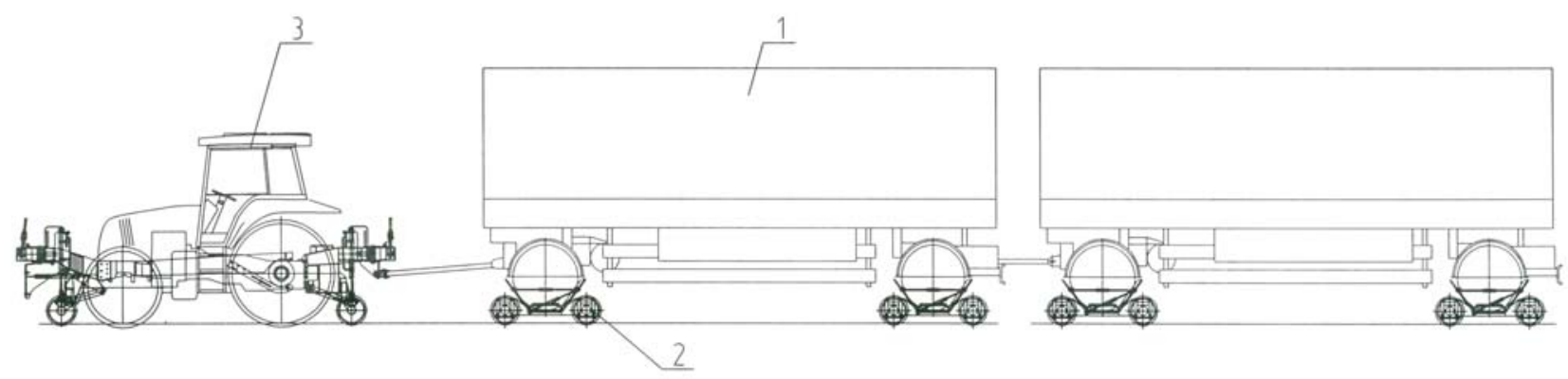

Rys. 1. System transportu przyczep drogowych po torach

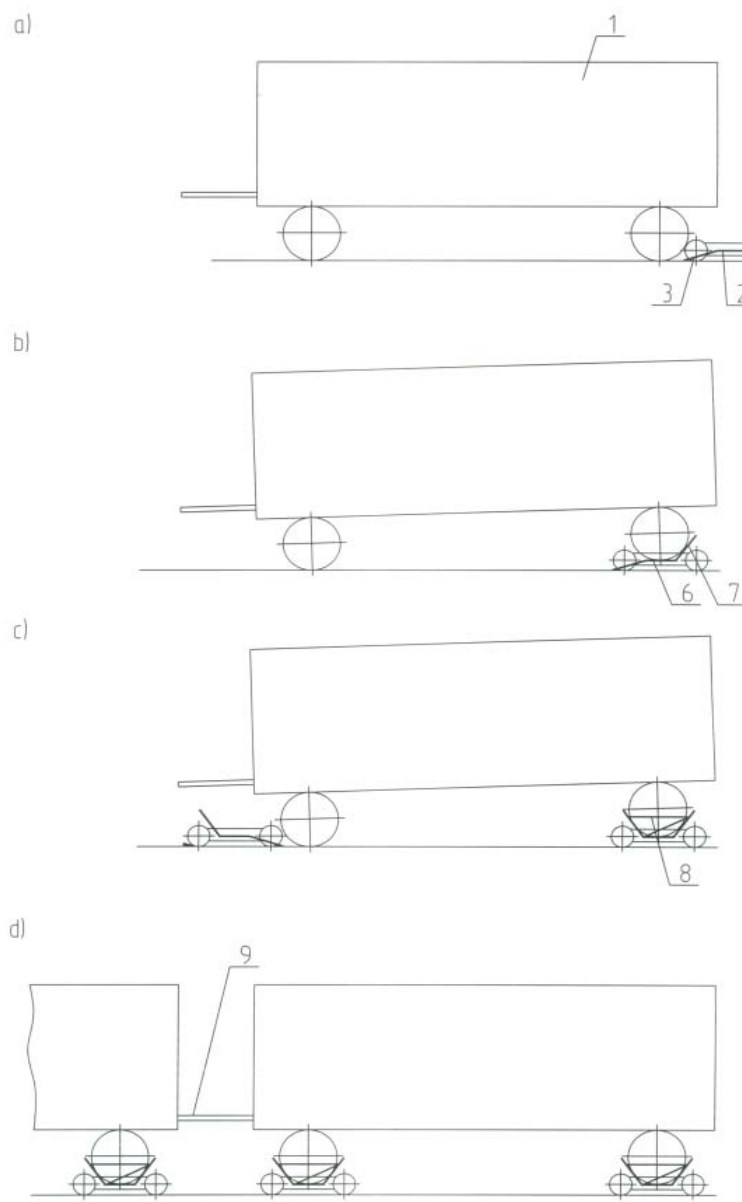

Rys. 2. Schemat faz montażu pociagu przyczep

Do montażu przyczep na wózkach transportowych potrzebny jest utwardzony plac z zabudowanym torem. Do tego celu może służyć również odpowiednio szeroki przejazd kolejowy.

Proces montowania pociagu przebiega $\mathrm{w}$ następujący sposób:

- przyczepę 1 ustawić w osi wzdłużnej toru, a za tylną osią przyczepy wstawić na tor wózek transportowy $2 \mathrm{z}$ odchylonymi pochylniami najazdowymi 3 opartymi jednym końcem o podłoże,

- wózek transportowy zabezpieczyć przed toczeniem, podkładając pod rolki jezdne 4 używane powszechnie w kolejnictwie „łyżwy hamujące” 5 (faza 2a),
- za pomocą ciagnika lub innego pojazdu trakcyjnego przepchnąć przyczepę w kierunku wózka transportowego, tak aby koła tylne przyczepy wtoczyły się po pochylni najazdowej na płytę nośną wózka, do oparcia kół o płyty oporowe 7 (faza $2 b)$,

- po ulokowaniu kół tylnych naczepy na wózku transportowym unieść pomosty najazdowe do kontaktu $\mathrm{z}$ oponami i zamocować pomosty ruchome do płyt oporowych za pomocą cięgieł zabezpieczających 8 . Postawić drugi wózek transportowy przed przednią osią przyczepy i w podobny sposób jak w przypadku załadunku osi tylnej, wprowadzić oś przednia na wózek transportowy (faza 2c),

- w przypadku tworzenia składu pociagu złożonego z dwóch lub trzech przyczep, przód i tył sąsiednich przyczep połączyć cięgłem pociagowym 9 (faza 2d).

\section{Opis budowy wózka transportowego}

Pokazany na rys. 3 wózek transportowy został zbudowany na bazie następujących zespołów: ramy wózka 1, belki obrotowej 2 i zestawów kołowych 3 .

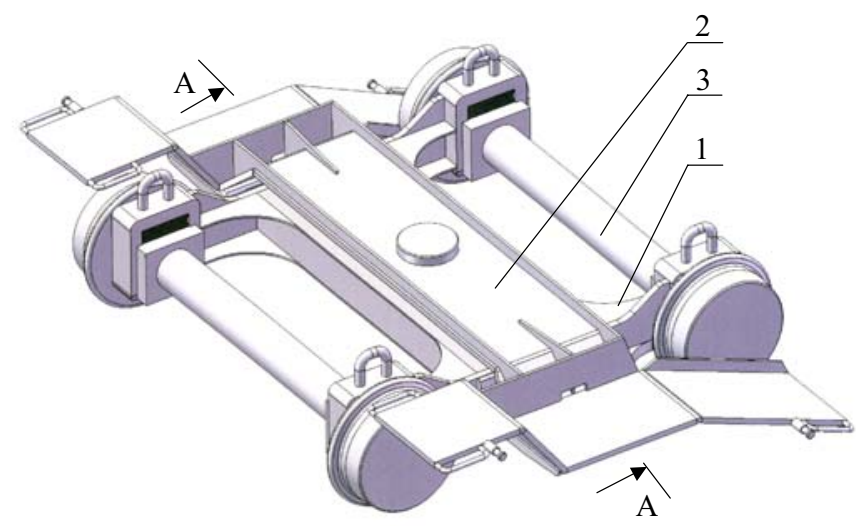

Rys. 3. Wózek transportowy

Ramę wózka przedstawiono na rys. 4 której główne elementy składowe to podłużnice 1 połączone belką poprzeczną 2. Podłużnice na końcach wyposażono w prowadnice 3 do zamocowania zestawów kołowych 
Belka poprzeczna $2 \mathrm{w}$ środkowej części została wyposażona w otwór czopa skrętu 4. Belka poprzeczna po zewnętrznych stronach podłużnic została zakończona płytami odpowiednio obniżonymi do poziomu wynikającego z dolnej części skrajni kolejowej 5 na których przymocowano płyty ślizgowe 6 .

Belka obrotowa pokazana na rys. 5 składa się z części środkowej 1, zaopatrzonej w sworzeń czopa skrętu 2. Końce belki wyposażono w obniżone płyty $3 \mathrm{z}$ prowadnicami 4.

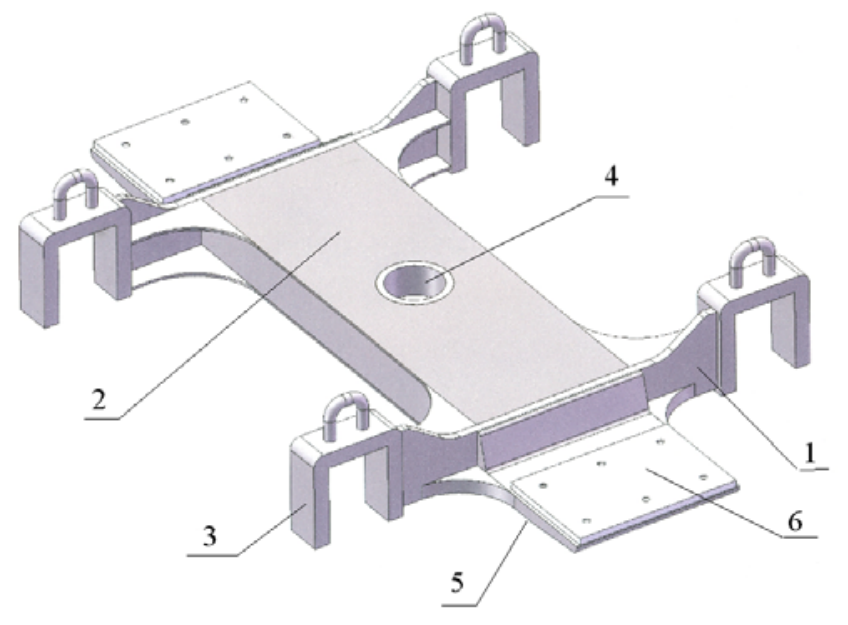

Rys. 4. Rama wózka

Na końcach płyty 3 zamocowano stała, pochyła, płytę oporową 5 oraz obrotową płytę najazdową 6 . Stałe pochylone płyty oporowe 5 są przedłużone płytami 7 , które połączono obrotowym zawiasem. Na płytach najazdowych 6 oraz na płytach 7 zamocowano po zewnętrznych stronach uchwyty 8 oraz sworznie 9 do mocowania cięgła zabezpieczającego koła naczepy na wózku.

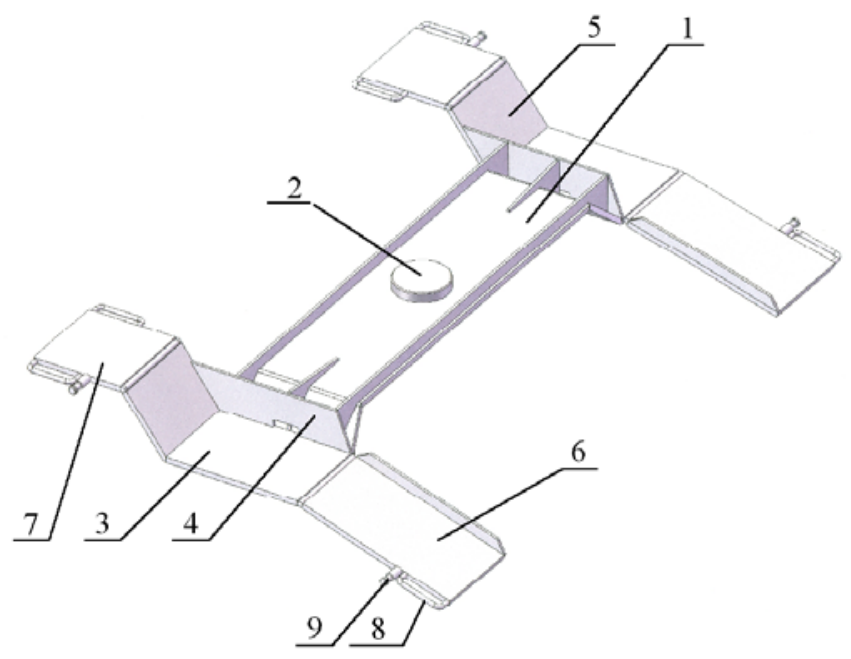

Rys. 5. Belka obrotowa

Na rys. 3 zaznaczono przekrój A-A który pokazano na rys. 6 gdzie przedstawiono sposób mocowania płyty obrotowej do ramy wózka oraz miejsce oparcia płyty obrotowej na ramie wózka.

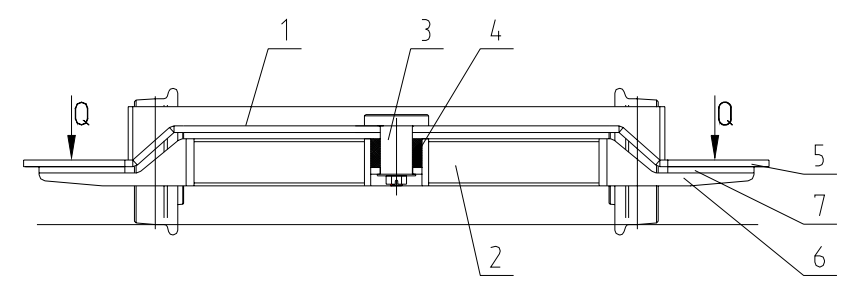

Rys. 6 Mocowanie płyty obrotowej

Płyta obrotowa 1 została zamocowana do belki poprzecznej ramy wózka 2 za pomocą sworznia 3 oraz tulei metalowo gumowej 4 wciśniętej w otwór wykonany w konstrukcji skrzynkowej belki poprzecznej. Połączenie przenosi w sposób elastyczny obciążenia poziome (boczne i wzdłużne) występujące między belką obrotową a ramą wózka.

Obciążenia pionowe "Q" pochodzące od ciężaru przyczepy są przyłożone do płyt poziomych 5 belki obrotowej, podpartych w tym miejscu wspornikami 6 będącymi zakończeniem belki poprzecznej ramy wózka. Pomiędzy wspornikami belek i płytami belki obrotowej zastosowano płyty ślizgowe 7 zmniejszające moment oporowy podczas obrotu belki obrotowej 6 względem ramy wózka.

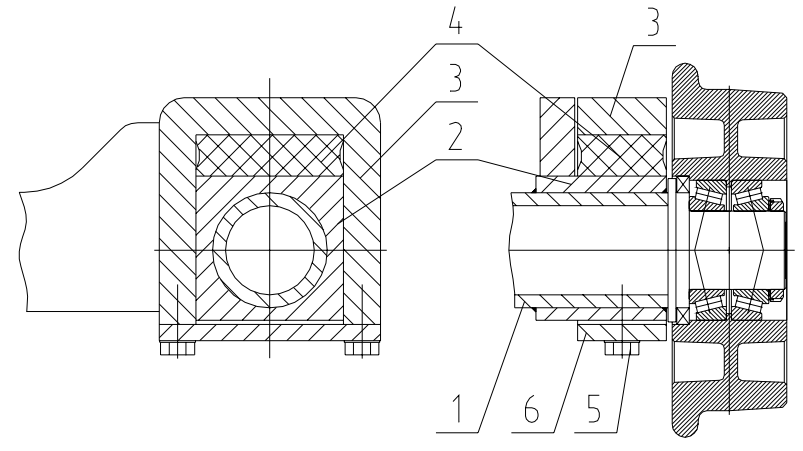

Rys. 7. Zabudowa zestawów kołowych

Osie zestawu kołowego rys. 7 zabudowano w prowadnicach ramy wózka tak aby w łatwy sposób możliwy był ich montaż i demontaż. Wózek jest przeznaczony do eksploatacji i po torach kolejowych i tramwajowych przez wymianę zestawów kołowych, ponieważ profile rolek jezdnych kolejowych różnią się od profilu rolek przeznaczonych do jazdy po torach tramwajowych. Oś zestawu kołowego jest złożona $\mathrm{z}$ rury 1 do której końców zamocowano ograniczniki 2 prowadzące poprzecznie i pionowo zestawy w ramie wózka. Prowadnice ramy wózka 3 opierają się na oprawach 2 za pośrednictwem elementów sprężystych 4.

Ograniczniki prowadzące 2 są suwliwe i pionowo prowadzone w prowadnicach ramy wózka a przesuw poprzeczny zestawu jest limitowany ogranicznikiem 2. Demontaż zestawu z ramy wózka sprowadza się do odkręcenia śrub mocujących 5 i zdjęcia zwory 6 zabezpieczającej zestaw kołowy w ramie wózka. 
Na rys. 8 pokazano wózek transportowy w stanie z przygotowanym do najazdu kół przyczepy a rys. 9 pokazuje wózek z zamocowaną i zabezpieczoną osią drogową przyczepy za pomocą urządzeń cięgłowych 1.

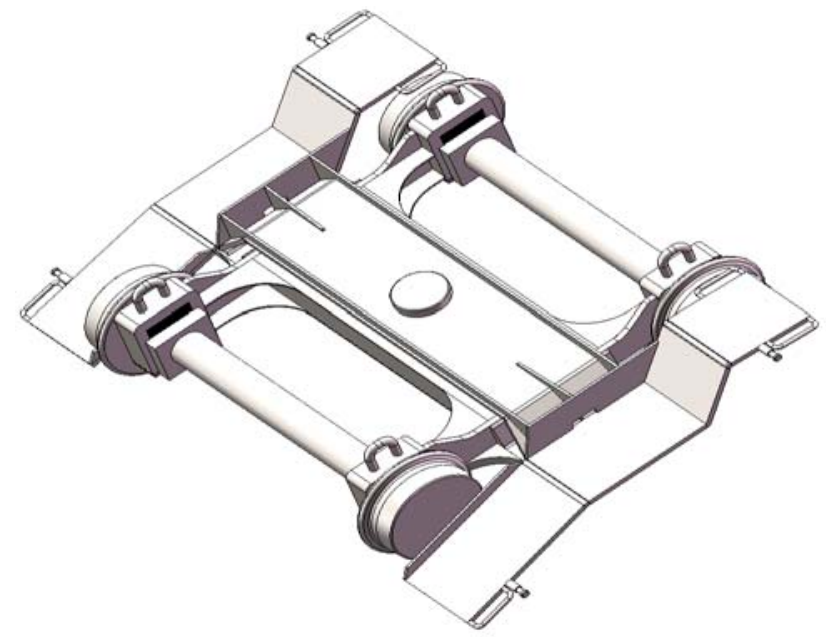

Rys. 8. Wózek przygotowany do najazdu kół przyczepy

Na rys 10 zaprezentowano odmianę wózka w której ślizgi boczne 1 umieszczono na górnej płycie belki poprzecznej. Pokonano również zakres obrotu belki obrotowej względem ramy wózka. Sytuacja taka ma miejsce podczas przejazdu wózków przez łuki kolejowe i tramwajowe. Swoboda kinematyczna obrotu belki względem ramy wózka zapewnia możliwość przejazdu wózka po łuku tramwajowym o małym promieniu $\mathrm{R} \geq 18 \mathrm{~m}$.

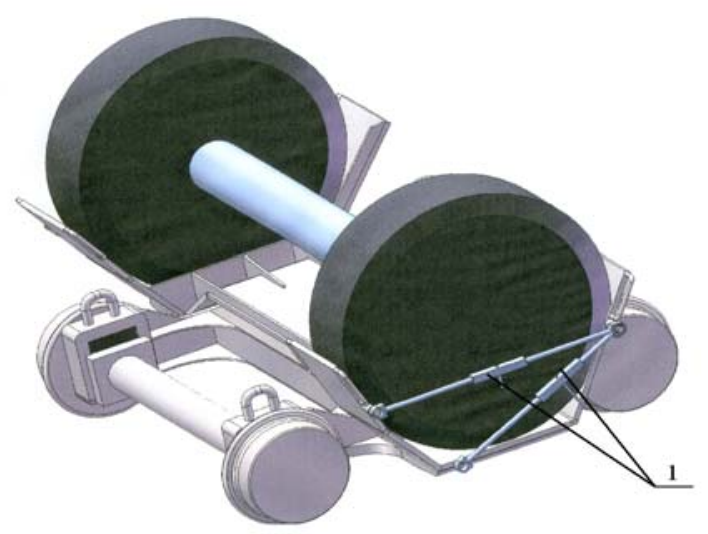

Rys. 9. Wózek z osią drogową przyczepy

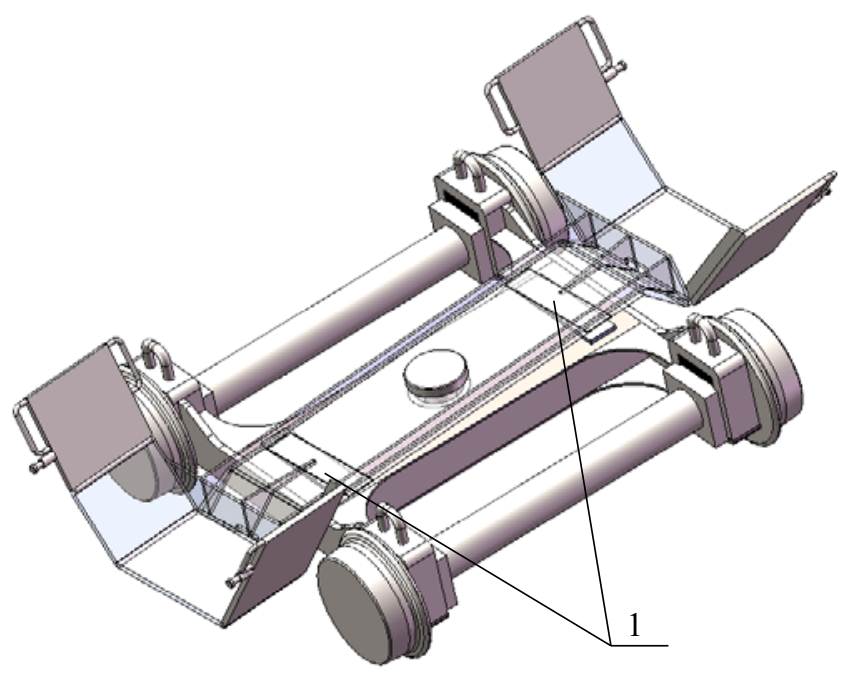

Rys. 10. Odmiana wózka ze ślizgami bocznymi umieszczonymi na belce poprzecznej

\section{Przykład wykorzystania systemu}

Przykład wykorzystania prezentowanej koncepcji systemu przedstawiono no rys. 11 i 12 .

Pokazano pociąg złożony $\mathrm{z}$ dwóch przyczep na których zamontowano urządzenia do montażu, naprawy lub przeglądu sieci trakcyjnej, kolejowej lub tramwajowej. Rozplanowanie oraz dobór wyposażenia nie jest obligatoryjny i może ulec zmianie w zależności od wymagań postawionych przez zamawiającego.

Rysunek 11 przedstawia pociag sieciowy w uformowaniu kolejowym a na rys 12 pokazano przyczepy w zestawieniu drogowym gdzie wózki transportowe przewożone są na pojeździe trakcyjnym.

Rysunek 13 pokazuje zakres pracy urządzeń obsługowych zabudowanych na pojeździe a na rysunku 14 przedstawia gabaryt poprzeczny przyczep na tle skrajni kolejowej wg UIC $-505-1$ oraz skrajni budowli wg PN-69/K-02057.

Rys. 11. Mobilny - szynowo drogowy pociagg sieciowy, w uformowaniu kolejowym

1 - urzadzenia pomiarowe sieci, 2 - wypornica sieci, 3 - koto zapasowe naczepy, 4 - bęben liny nośnej, 5 - bęben przewodu sieciowego, 6 - zuraw $12 \mathrm{~m}(9 \mathrm{tm}), 7$ - pantograf sieciowy, 8 zbiornik hydrauliczny, 9 - agregat spalinowy, 10 - kosz żurawia $(2,6 \mathrm{kN})$, podest obstugowy (4 kN), 12 - skrzynia ładunkowa

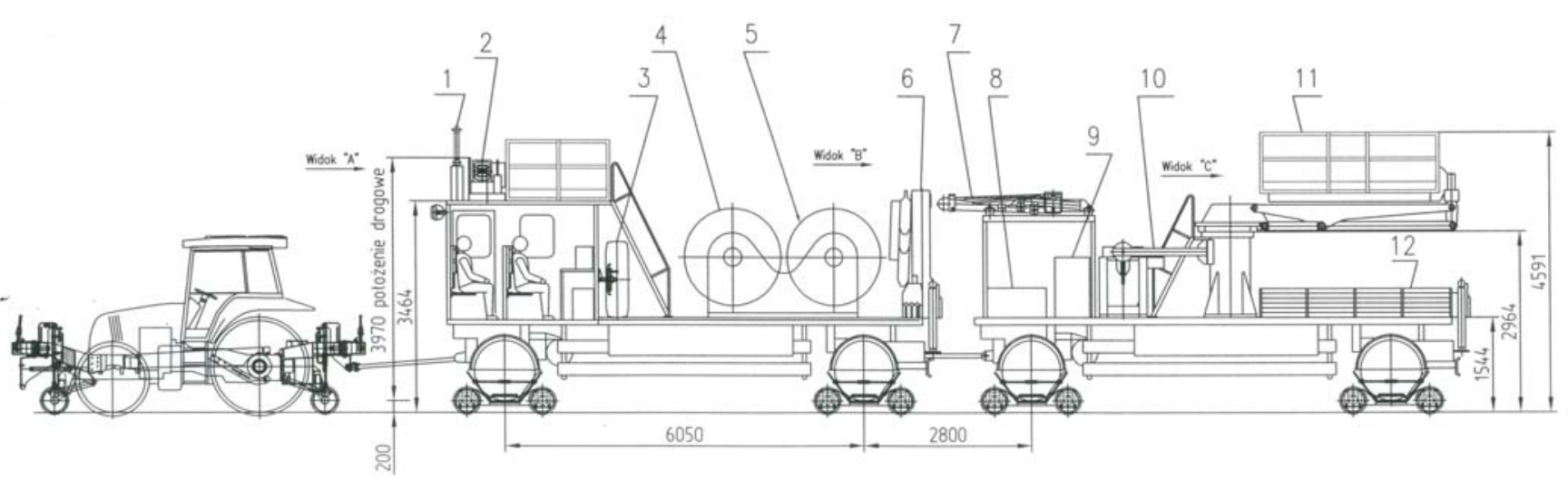




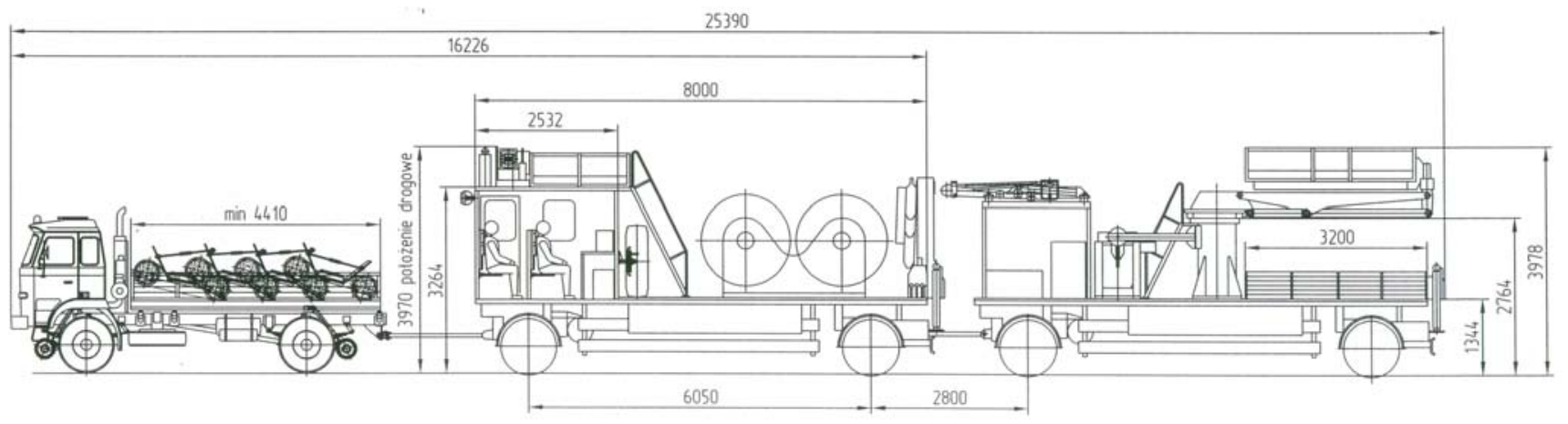

Rys. 12. Mobilny - szynowo drogowy pociąg sieciowy, w uformowaniu drogowym

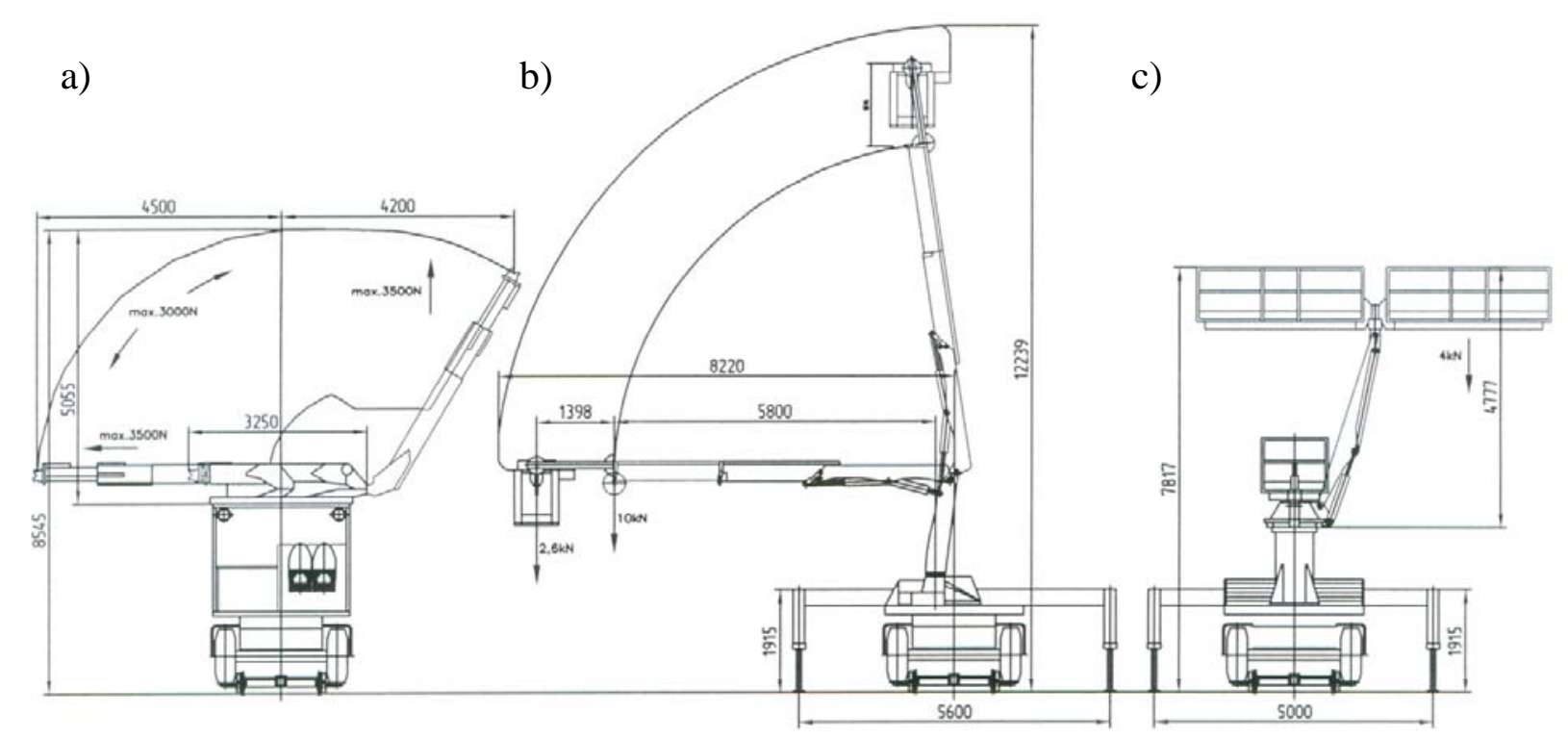

Rys. 13. Zakres pracy urządzeń zabudowanych na przyczepach: a) wypornicy, b) żurawia, c) platformy obsługowej
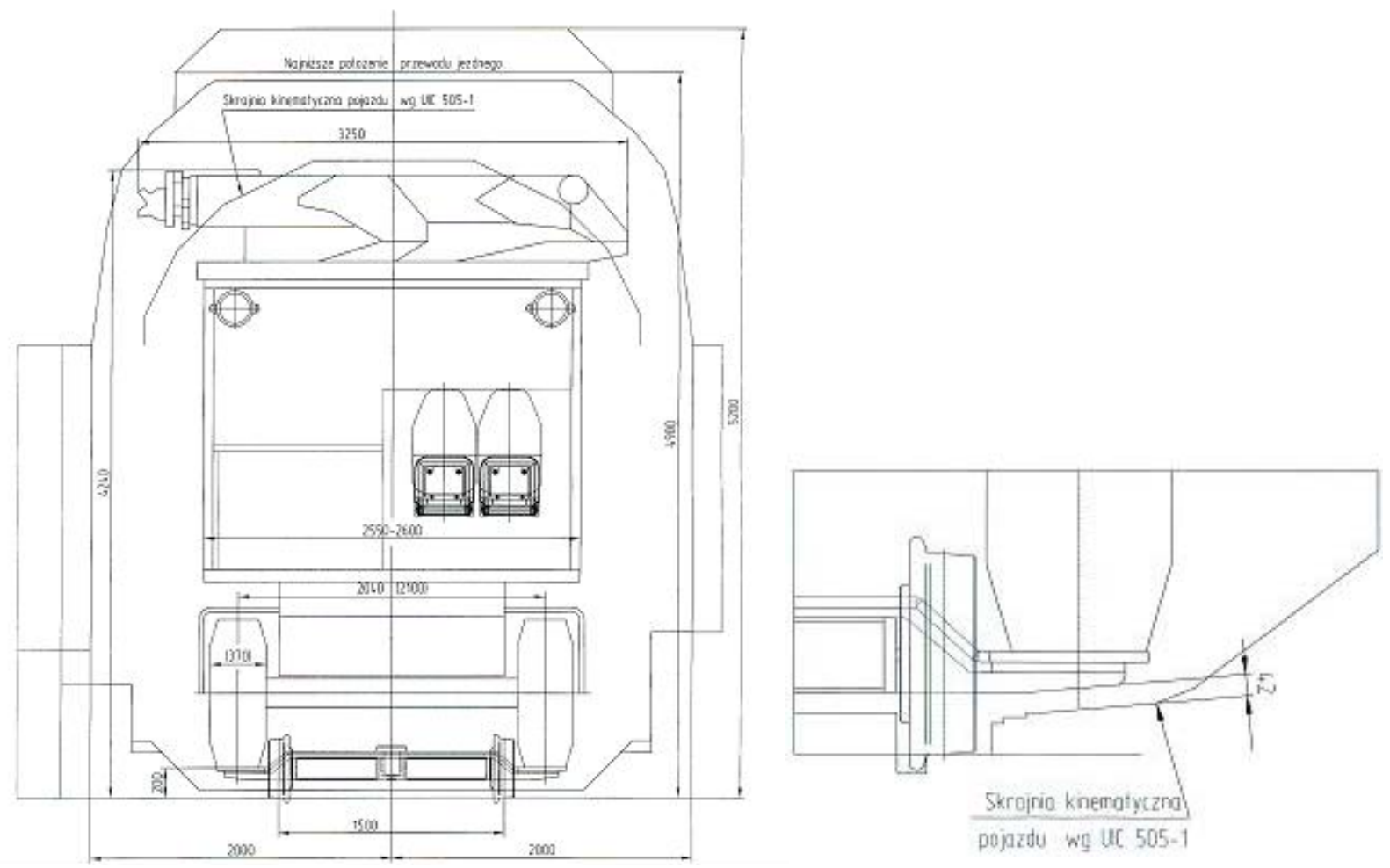

Rys. 14. Przyczepa z wyposażeniem na tle skrajni 


\section{System transportu przyczep drogowych $z$ wla- snym napędem do jazdy po torach}

Przedstawioną w punkcie 3 koncepcję budowy tocznego wózka transportowego rozwinięto, wyposażając go w silniki hydrauliczne napędne i hamujące koła jezdne wózka.

Strukturę budowy wózka napędnego przedstawiono na rys 15 .

Końce ramy wózka 1 wyposażono w prowadzenia widłowe $2 \mathrm{w}$ których zamontowano suwliwie prowadniki 3. Na prowadnikach, od strony wewnętrznej ramy wózka zamocowano silniki hydrauliczne 4, a po stronie zewnętrznej ułożyskowano koła jezdne $5 \mathrm{w}$ sposób umożliwiający przeniesienie momentu obrotowego z wałka silnika hydraulicznego na koło jezdne. Pomiędzy dolną powierzchnią prowadnika 3 wprowadzono element sprężysty 6 a prowadnik 3 od dołu zamknięto zworą 7 przymocowaną do prowadników 2 śrubami 8. Do przeniesienia sił wzdłużnych (napędowych i hamujących) z ramy wózka na ramę przyczepy zastosowano sztywne cięło 9, zamocowane jednym końcem do belki obrotowej 10 wózka, a drugim końcem do wspornika ramy przyczepy.

$\mathrm{Na}$ rys. 16 przedstawiono wózek w którym prowadniki 3 (rys. 15) połączono listwami $1 \mathrm{w}$ celu odciążenia powierzchni ciernych prowadnic od działania sił poziomych pochodzących od obciążenia pionowego kół jezdnych wózka oraz sił prowadzących wózek w torze.

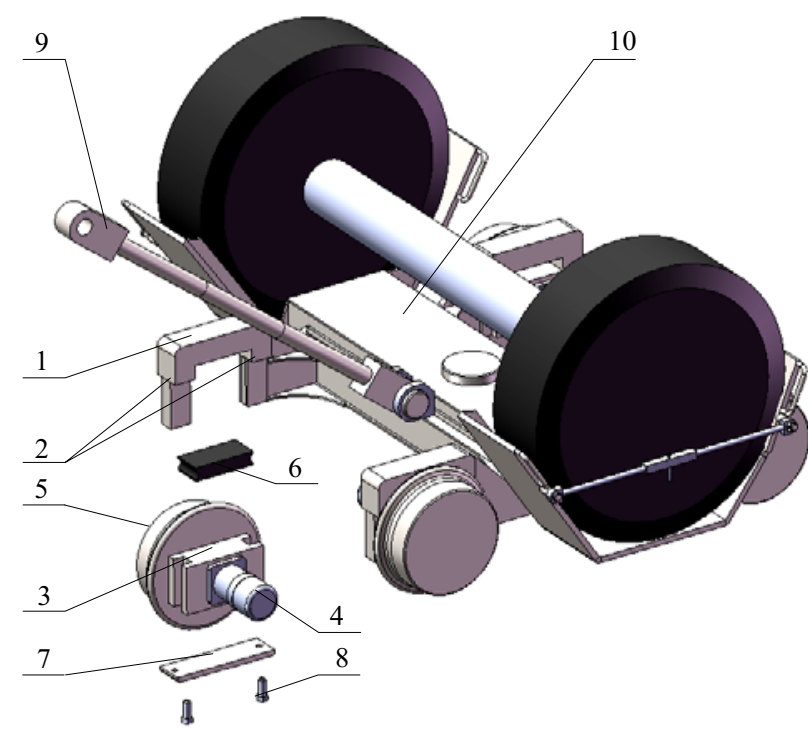

Rys. 15 Struktura budowy napędnego wózka transportowego

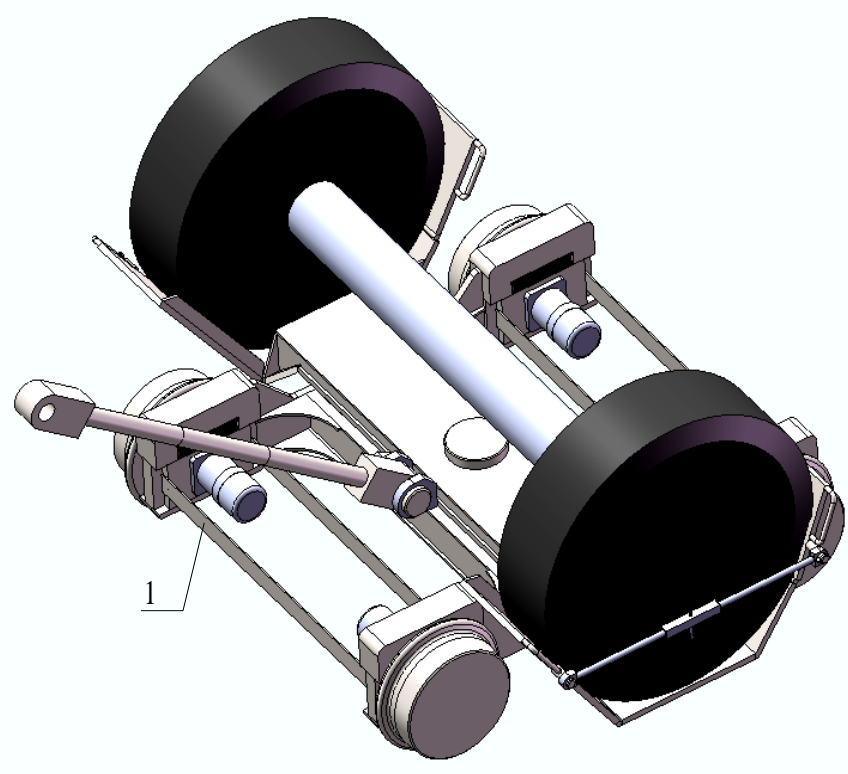

Rys. 16. Odmiana wózka z łącznikami prowadników

\section{Samojezdny system w uformowaniu kolejowym i drogowym}

Na rys. 17 przedstawiono koncepcję samojezdnego pociągu sieciowego złożonego $\mathrm{z}$ dwóch przyczep drogowych. Pierwszą przyczepę wyposażono między innymi $\mathrm{w}$ kabinę sterowniczą $\mathrm{z}$ pulpitem $\mathrm{w}$ którym zabudowano urządzenia sterowania jazdą $i$ hamowaniem pociąu. Za kabiną umieszczono agregat spalinowo hydrauliczny do zasilania układu jazdy po torach oraz urządzeń dźwigowych zabudowanych na pojeździe. Układ jazdy po torach stanowią wózki napędne na których posadowiono pierwszą przyczepę. Drugą przyczepę zamocowano na wózkach tocznych.

Sterowanie rozruchem jazdy i hamowaniem pociągu może być prowadzone za pomocą dżojstika umieszczonego na pulpicie sterującym. Wysoko momentowe, wolnoobrotowe silniki hydrauliczne napedzające koła jezdne wózków są wyposażone fabrycznie $\mathrm{w}$ hamulec postojowy. Maksymalna prędkość ruchu pociagu wynosi $\sim 10 \mathrm{~km} / \mathrm{h}$.

Prezentowany system posiada tylko jedną kabinę $\mathrm{z}$ widocznością $\mathrm{w}$ jedną stronę. $\mathrm{W}$ celu zapewnienia możliwości poruszania się $\mathrm{w}$ stronę przeciwną niż kierunek zwrócenia kabiny zastosowano kamerę, która pozwala na obserwację toru. Drugą możliwością jest wyposażenie systemu $\mathrm{w}$ stopień manewrowy. Znajdujący się na stopniu pracownik obserwuje szlak a następnie za pomocą systemu łączności radiowej przekazuje informacje do kabiny sterowniczej. System taki jest możliwy z uwagi na warunki pracy: niewielka prędkość, oraz praca na zasadach pracy manewrowej. $\mathrm{Na}$ rys 18 pokazano zestaw pociagu sieciowego podczas jazdy drogowej. 


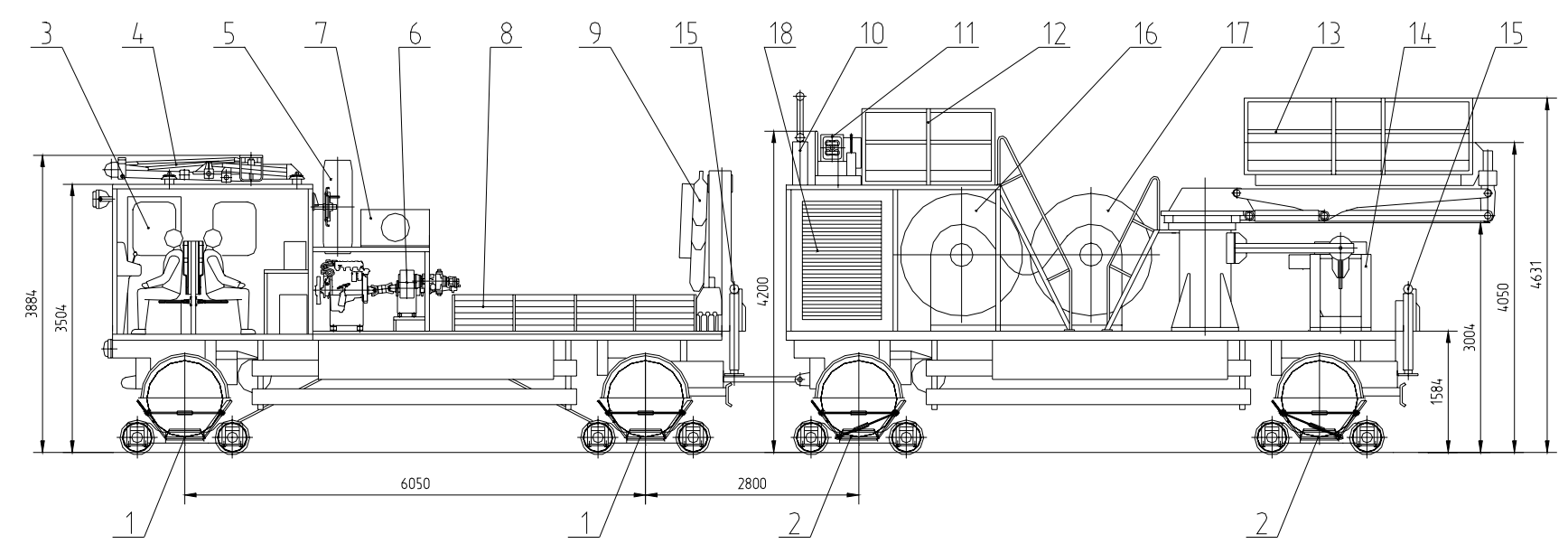

Rys. 17. Mobilny, szynowo - drogowy, pociag sieciowy z własnym napędem jazdy w uformowaniu kolejowym:

1- wózek jezdny z napędem hydraulicznym jazdy, 2 - wózek jezdny, toczny, 3 - kabina operatora i obstugi urzqdzeń pojazdu, 4 - pantograf sieciowy, 5 - koło zapasowe pojazdu, 6-agregat spalinowo hydrauliczny, 7 - zbiornik oleju, 8 - skrzynia tadunkowa, 9 -żuraw $12 \mathrm{~m}$ (9 tm), 10 - urzadzenie pomiarowe sieci, 11 - wypornica hydrauliczna sieci, 12 - pomost obstugowy staty, 13 - podest obstugowy ruchomy (4 kN), 14 - kosz obstugowy żurawia (2,6 kN), 15 - podpory hydrauliczne, 16 - bęben liny nośnej, 17 - bęben przewodu sieciowego, 18 - kabina narzędziowa z żaluzjami zamykajacymi

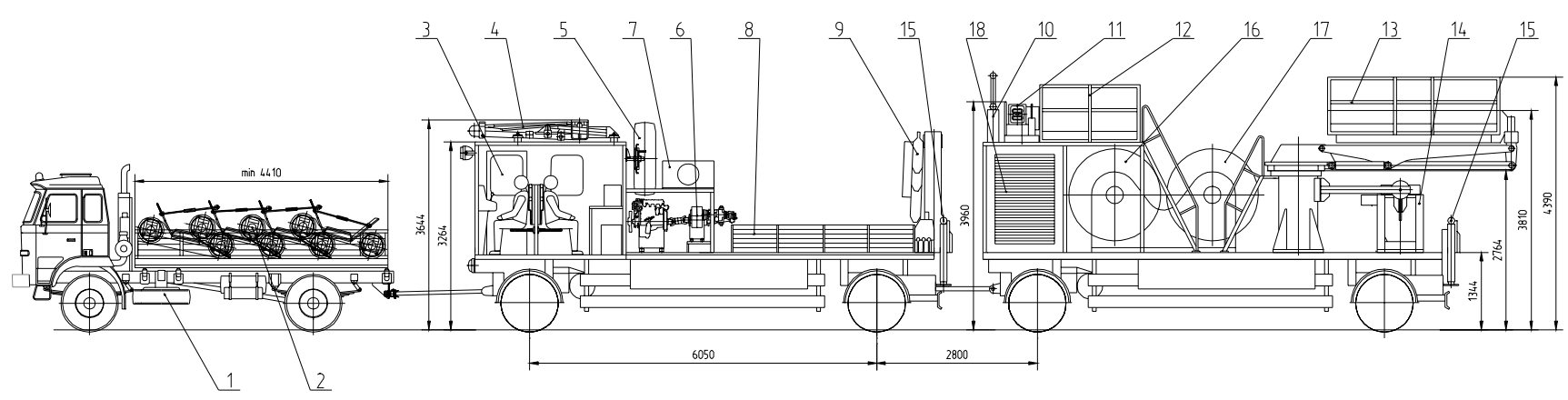

Rys. 18. Mobilny, szynowo - drogowy, pociag sieciowy w uformowaniu drogowym:

1- samochód ciężarowy np.: 10,5 tonowy, 2 - wózek jezdny, napędny i toczny, 3 - kabina operatora i obstugi urzadzeń pojazdu, 4-pantograf sieciowy, 5 - koło zapasowe pojazdu, 6 - agregat spalinowo hydrauliczny, 7 - zbiornik oleju, 8 skrzynia ładunkowa, 9 - zuraw $12 \mathrm{~m}$ (9 tm), 10 - urzadzenie pomiarowe sieci, 11 - wypornica hydrauliczna sieci, 12 pomost obstugowy staty, 13 - podest obstugowy ruchomy (4 kN), 14 - kosz obstugowy żurawia (2,6 kN), 15 - podpory hydrauliczne, 16 - bęben liny nośnej, 17 - bęben przewodu sieciowego, 18 - kabina narzędziowa z żaluzjami zamykajacymi

\section{Podsumowanie}

Zaprezentowane koncepcje wykorzystania przyczep drogowych do manewrowego ruchu kolejowego winny być rozwijane i dopracowywane w dalszych etapach prac projektowo badawczych. Oferowane koncepcje uzupełniają istniejący stan techniki i stanowią niekonwencjonalną odmianę transportu kombinowanego, kolejowo drogowego. Przedstawiony przykład zastosowania systemu jest jednym z możliwych sposobów jego wykorzystania i zależy od rodzaju wyposażenia przyczep w urządzenia specjalistyczne.

Koncepcje systemu oraz przyjęte rozwiązania techniczne zostały zgłoszone do ochrony patentowej $\mathrm{w}$ Urzędzie Patentowym RP.

\section{Literatura}

[1] Karta UIC 505-1. Pojazdy kolejowe. Skrajnie pojazdów. 9-te wydanie z 01.11.2003,

[2] PN-69/K-02057. Koleje normalnotorowe. Skrajnia budowli,

[3] Karty katalogowe firmy PALFINGER,

[4] OR - 9671 Dobór wstępny parametrów hydraulicznych wózków napędnych do transportu przyczep drogowych typu PSD Archiwum IPS „TABOR”. 